\title{
DIRECTIVE 2013/48/EU AND THE REQUESTED PERSON'S RIGHT TO APPOINT A LAWYER IN THE ISSUING MEMBER STATE IN EUROPEAN ARREST WARRANT PROCEEDINGS
}

\author{
Prof. dr. Vincent Glerum*
}

\begin{abstract}
Directive 2013/48/EU gives persons who are subject to European arrest warrant proceedings the right to "dual representation": not only the right of access to a lawyer in the executing Member State but also the right to appoint a lawyer in the issuing Member State, whose limited role it is to provide information and advice to the lawyer in the executing Member State with a view to the effective exercise of the requested person's rights under Framework Decision 2002/584/ JHA. The right to appoint a lawyer in the issuing Member State is supposed to contribute to facilitating judicial cooperation. This article takes a closer look at that right and tries to establish whether - and, if so, to what extent - that right does indeed facilitate judicial cooperation.
\end{abstract}

Key words: Directive 2013/48/EU; European arrest warrant; dual representation; rights under Framework Decision 2002/584/JHA

Professor (by special appointment) of international and European criminal law, University of Groningen; legal advisor to the Extradition Chamber of the District Court of Amsterdam (the Netherlands); e-mail: v.h.glerum@rug.nl; https://orcid.org/0000-00017668-1939. 


\section{INTRODUCTION}

According to the Framework Decision 2002/584/JHA on the European arrest warrant ${ }^{1}$ (FD 2002/584/JHA), the person against whom a European arrest warrant (EAW) is issued - the requested person - has a number of procedural rights in EAW proceedings in the executing Member State (MS).

One of those minimum rights ${ }^{2}$ is the right of a requested person who is arrested pursuant to an EAW "to be assisted by a legal counsel (...) in accordance with the national law of the executing [MS]" (Art. 11(2)) Directive $2013 / 48 / \mathrm{EU}$ on the right of access to a lawyer ${ }^{3}$ aims at facilitating judicial cooperation on the basis of the principle of mutual recognition. Its legal basis is to be found in Art. 82(2) TFEU, which confers the power to harmonize certain aspects of criminal procedural law " $(t)$ o the extent necessary to facilitate mutual recognition of judgments and judicial decisions and police and judicial cooperation in criminal matters having a cross-border dimension". According to the preamble of the directive, the principle of mutual recognition presupposes mutual trust, but experience has shown that the mere fact that all MSs are party to the ECHR and the ICCPR does not always provide a sufficient degree of trust in the criminal justice systems of the MSs. ${ }^{4}$ For that reason, mutual trust must be strengthened by providing detailed common minimum rules on, inter alia, the right of access to a lawyer in EAW proceedings.

That right does not derive from Art. 6(1) of the ECHR, because this provision does not apply to the EAW. "[E]xtradition proceedings, including the procedure for executing [an EAW]" do not involve the determi-

1 Framework Decision 2002/584/JHA of the Council of 13 June 2002 on the European arrest warrant and the surrender procedures between Member States, OJ L 190/1.

2 ECJ, judgment of 3 May 2007, Advocaten voor de Wereld, C-303/05, ECLI:EU:C:2007:261, \$30.

3 Directive 2013/48/EU of the European Parliament and of the Council of 22 October 2013 on the right of access to a lawyer in criminal proceedings and in European arrest warrant proceedings, and on the right to have a third party informed upon deprivation of liberty and to communicate with third persons and with consular authorities while deprived of liberty, OJ L 294/1. Denmark and Ireland are not bound by this directive.

Recitals (4)-(5). 
nation of the requested person's civil rights or obligations or of a criminal charge against him ${ }^{5}$. Art. 47(2) of the Charter of Fundamental Rights of the European Union (Charter), however, has a wider scope: it is not limited to the determination of civil rights and obligations or the determination of a criminal charge. The preamble of Directive 2013/48/EU states that by laying down rules about, inter alia, access to a lawyer in EAW proceedings, the directive promotes the application of, inter alia, Art. 47 of the Charter ${ }^{6}$. In other words, the directive promotes the application of the right to fair EAW proceedings.

For the 25 MSs bound by Directive 2013/48/EU, the directive puts the requested person's right of access to a lawyer in the executing MS on a more secure footing. Whereas Art. 11(2) of FD 2002/584/JHA leaves unanswered what is to be understood by "assistance" and, moreover, refers to the national law of the executing MS, Art. 10(1) of Directive 2013/48/EU obliges the MSs "to ensure that a requested person has the right of access to a lawyer in the executing [MS] upon arrest pursuant to the [EAW]" without referring to the national law of the executing MS and Art. 10(2) sums up which rights are contained in the right of access to a lawyer in the executing MS.

But the directive goes further still and confers a right to "dual representation": 7 the requested person also has a right to appoint a lawyer in the issuing MS (Art. 10(4) of Directive 2013/48/EU).

The preamble to the directive does not make clear how facilitating the right to appoint a lawyer in the issuing MS could contribute to facilitating judicial cooperation. The Explanatory Memorandum to the Commission

5 See ECtHR, decision of 25 June 2019, West v. Hungary, ECLI:CE:ECHR:2019:0625DEC000538012, \$65. See also ECtHR, decision of 7 October 2008, Monedero Angora v. Spain, ECLI:CE:ECHR:2008:1007DEC004113805 and ECtHR, decision of 24 March 2015, Martuzevičius v the United Kingdom, ECLI:CE:ECHR:2015:0324DEC001356613, $\$ 32$. The case-law on the non-applicability of Art. 6(1) of the ECHR to extradition proceedings is abundant. See, e.g., ECtHR, judgment of 4 February 2005, Mamatkulov and Askarov v. Turkey [GC], ECLI:CE:ECHR:2005:0204JUD004682799, \$82.

6 Recital (12).

7 EU Fundamental Rights Agency (FRA), Rights in practice: access to a lawyer and procedural rights in criminal and European arrest warrant proceedings, Luxembourg: Publications Office of the European Union, 2019, 64. 
proposal for the directive is somewhat more enlightening. It gives two examples of assistance by a lawyer in the issuing MS: (1) such assistance can facilitate the effective exercise of the requested person's rights, in particular the possibility to invoke a ground for non-execution and (2) such assistance will result in speedier consent to surrender by requested persons (Art. 13(1) of FD 2002/584/JHA), because they will have fuller information on the proceedings in the issuing MS and on the consequences of their consent ${ }^{8}$. Apparently, the idea behind the first example is that the quality of any argument against the execution of the EAW will improve, because only valid and well-founded reasons for non-execution will be put forward. In other words, judicial cooperation will be enhanced because the number of unjustified refusals will be reduced and the quality of decisions to surrender will be improved. The second example is clear in and of itself: speedier consent to surrender means speedier surrender.

In other Commission documents, yet another example is given: assistance by a lawyer in the issuing MS by providing information about the legal situation and the case-file in the issuing Member State is likely to reduce the incidence of cases in which an EAW was executed which was later shown to have been issued wrongly ${ }^{9}$, which, as it happens, is still an issue ${ }^{10}$. Obviously, this would foster mutual trust and, thus, contribute to facilitating judicial cooperation.

All of these examples presume that the lawyer in the issuing MS has the specialized knowledge and experience required to provide information and advice which is relevant to the exercise of the requested person's rights under FD 2002/584/JHA and also the means to provide such relevant information and advice (access to the criminal case-file).

$8 \operatorname{COM}(2011) 326$ final, 8-9.

9 Impact assessment accompanying the proposal for a Directive of the European Parliament and of the Council on the rights of access to a lawyer and of notification of custody to a third person in criminal proceedings, SEC(2011) 686, 33; Impact assessment accompanying the Proposal for Measures on Legal Aid for Suspects or Accused Persons in Criminal Proceedings, SWD(2013) 476 final, 19-20.

${ }_{10}$ On the abuse or misuse of the EAW see Fair Trials, Beyond Surrender. Putting human rights at the heart of the European Arrest Warrant, 2018: 9-16. May 2 $2^{\text {nd }}, 2020$, https:// www.fairtrials.org/publication/beyond-surrender. 
This article takes a closer look at the right to appoint a lawyer in the issuing MS and tries to establish whether - and, if so, to what extent - that right can contribute to achieving the directive's goal of facilitating judicial cooperation. ${ }^{11}$ Unlike some of the other contributions to this special issue of the Review of European and Comparative Law, this article tackles its subject primarily from an EU law perspective.

To that end, first the relevant provisions of Directive 2013/48/EU are discussed (para. 2). Then the focus shifts to the role of lawyer in the issuing MS (paras. 3 and 4). By analysing his role and the limits to that role,

11 There is abundant literature on the right of access to a lawyer and Directive 2013/48/EU. See, e.g.: Ilias Anagnostopoulos, "The Right of Access to a Lawyer in Europe: A Long Road Ahead?", European Criminal Law Review 1(2014), 3-18; Teresa Armenta Deu, Lisa Urban, “The Right of Access to a Lawyer under Directive 2013/48/EU”, In: Effective Defence Rights in Criminal Proceedings. A European and Comparative Study on Judicial Remedies, ed. Silvia Allegrezza, Valentina Covolo, Milano: Wolters Kluwer, 2018, 65-79; Lorena Bachmaier Winter, "The EU Directive on the Right to Access to a Lawyer: A Critical Assessment”, In: Human Rights in European Criminal Law. New Developments in European Legislation and Case Law after the Lisbon Treaty, ed. Stefano Ruggeri, Cham: Springer 2015, 111-131; Steven Cras, "The Directive on the Right of Access to a Lawyer in Criminal Proceedings and in European Arrest Warrant Proceedings”, eucrim 1(2014): 32-44; Zlata Đurđević, "The Directive on the Right of Access to a Lawyer in Criminal Proceedings: Filling a Human Rights Gap in the European Union Legal Order”, In: ed. Zlata Đurđević, Elizabeta Ivičević Karas, European Criminal Procedure Law in Service of the Protection of European Union Financial Interests: State of Play and Challenges, Zagreb: Croatian Association of European Criminal Law, 2016: 9-23; Mar Jimeno-Bulnes, "The Right of Access to a Lawyer in the European Union: Directive 2013/48/EU and Its Implementation in Spain”, In: EU Criminal Justice. Fundamental Rights, Transnational Proceedings and the European Public Prosecutor's Office, ed. Tommasso Rafaraci, Rosanna Belfiore, Cham: Springer, 2019, 57-70; Anneli Soo, "Potential Remedies for Violation of the Right to Counsel in Criminal Proceedings: Article 12 of the Directive 2013/48/EU (22 October 2013) and its Output in National Legislation", European Criminal Law Review 3(2016): 284-307; Anneli Soo, "Article 12 of the Directive 2013/48/EU: A Starting Point for Discussion on a Common Understanding of the Criteria for Effective Remedies of Violation of the Right to Counsel", European Journal of Crime, Criminal Law and Criminal Justice 1(2017): 31-51; Elisavet Symeonidou-Kastanidou, "The Right of Access to a Lawyer in Criminal Proceedings: The transposition of Directive 2013/48/EU of 22 October 2013 on national legislation”, European Criminal Law Review 5(2015): 68-85.

With some exceptions, the literature only makes a passing reference to the issue of "dual representation". 
paragraph 3 establishes what "dual representation" is not intended to do. In order to determine what it is intended to do, paragraph 4 examines what is meant by the expression "rights of requested persons under [FD] 2002/584/JHA", because assistance by a lawyer in the issuing MS is aimed at the effective exercise of those rights. The same paragraph also discusses whether and to what extent that assistance is relevant to that purpose. Once the objective of "dual representation" and the extent of its potential to contribute to the effective exercise of the requested person's rights are established, two more issues need to be discussed which are relevant to the functioning of the right to appoint a lawyer in the issuing MS: the duty to observe the short time-limits for taking a decision on the execution of the EAW (para. 5) and the scope of the effective remedy against a breach of that right (para. 6). Finally, paragraph 7 draws conclusions and contains some final considerations.

\section{THE RIGHT TO APPOINT A LAWYER IN THE ISSUING MS}

The directive applies to requested persons from the time of their arrest in accordance with Art. 10 (Art. 2(2)).

Art. 10(1)-(3) concerns the right of access to a lawyer in the executing MS. Art. 10(4) provides for the right to appoint a lawyer in the issuing MS. That lawyer's role is "to assist the lawyer in the executing [MS] by providing that lawyer with information and advice with a view to the effective exercise of the rights of requested persons under [FD] 2002/584/JHA". To that end, the competent authority in the executing MS must inform the requested person "without undue delay after deprivation of liberty" that he has that right ${ }^{12}$.

If a requested person who does not already have a lawyer in the issuing MS wishes to exercise the right to appoint a lawyer in the issuing MS, the competent authority in the executing MS must "promptly" contact its counterpart in the issuing MS and inform the latter of the requested person's wish (Art. 10(5)). Thereupon, the competent authority in the issuing

12 On the genesis of Art. 10(4)-(6) of Directive 2013/48/EU see Cras (2014), supra footnote 11: 42-43. 
MS is obliged to furnish the requested person, "without undue delay", with information to facilitate the requested person in appointing a lawyer in the issuing MS (Art. 10(5)). Recital (46) of the preamble states that such information could "include a current list of lawyers, or the name of a lawyer on duty in the issuing State, who can provide information and advice in [EAW] cases".

Art. 10(6) declares that the right to appoint a lawyer in the issuing MS is without prejudice to both the time-limits set out in FD 2002/584/ JHA and the executing judicial authority's duty "to decide, within those time-limits and the conditions defined under that [FD], whether the person is to be surrendered". Recital (47) explains that "while requested persons should be able to exercise fully their rights under this Directive in [EAW] proceedings, those time-limits should be respected", because observance of those time-limits is essential for the surrender procedure and the surrender procedure is crucial for cooperation in criminal matters between the MSs.

Before Directive 2013/48/EU, appointing a lawyer in the issuing MS was a matter of national law, in combination with Art. 6 of the ECHR. Because a person against whom a prosecution-EAW was issued, was, logically, also a suspect or an accused person in the issuing MS, he at least had the right to legal assistance in that State when he was charged with a criminal offence (Art. 6(3)(c) of the ECHR).

Art. 10(4) confirms that right and confers it on all requested persons from the time of their arrest pursuant to an EAW, whether they are sought for prosecution or for execution of a sentence.

Art. 10(4) speaks of "the right to appoint", not of the "right of access to" a lawyer in the issuing MS. Compared to the latter, the former right is much more limited. Art. 10(4)-(5) provides for the minimum obligations required to enable the requested person to exercise that right. Given the minimal degree of harmonization pursued, it was obviously not the aim to regulate that right - viz. the obligations to facilitate exercising that right - completely and exhaustively ${ }^{13}$. Other issues than those dealt with

13 For a critical assessment see Bachmaier Winter, supra footnote 11: 123, according to whom the right to appoint a lawyer in the issuing MS might be insufficient to provide effective protection. 
in Art. 10(4)-(5) are left to national law ${ }^{14}$. Consequently, once the competent authorities acquit themselves of the obligations mentioned in those provisions, the actual appointment of the lawyer in the issuing MS is the sole responsibility of the requested person.

For example, the directive does not give the competent authority in the executing MS any role in establishing contact with a lawyer in the issuing MS. Accordingly, in practice, apart from informing the requested person of his right, the competent authorities do not seem to provide any assistance in this regard ${ }^{15}$. The requested person can ask his lawyer in the executing $\mathrm{MS}$ or his relatives to contact a lawyer in the issuing $\mathrm{MS}^{16}$. Equally, there is no obligation to provide the lawyer in the issuing MS with the EAW. Again, the lawyer in the executing MS can play a role in this regard. The effectiveness of the defence mounted in the executing MS depends on the quality of the information and advice given by the lawyer in the issuing $\mathrm{MS}^{17}$, but Directive 2013/48/EU does not contain any provision designed to guarantee that the assistance provided by that lawyer conforms to professional standards. In the communications between the lawyer in the issuing MS and the lawyer in the executing MS, language barriers may be a problem ${ }^{18}$, but, again, the minimum provisions of the directive do not touch upon this topic.

Financial considerations present another practical challenge to "dual representation" ${ }^{19}$. The directive does not cover the right to legal aid (Art.

14 Compare ECJ, judgment of 19 September 2018, Milev, C-310/18 PPU, ECLI:EU:C:2018:732, \$47-48, concerning Art. 6 of Directive 2016/343/EU.

15 FRA, supra footnote 7: 65-66.

16 Compare ECtHR, decision of J July 2015, Arapiv. Albania, ECLI:CE:ECHR:2015:0707DEC002765607, \$72. The applicant was held in in custody in Belgium pending extradition proceedings. One of his complaints against the requesting State, Albania, was declared inadmissible for non-exhaustion of domestic remedies. It was not shown that the applicant was prevented from taking any steps "whether through the assistance of a Belgian lawyer, or through the assistance of his relatives or directly, to contact a lawyer in Albania" in order to challenge the Albanian detention order.

17 Martha Bargis, "Personal Freedom and Surrender", In: Handbook of European Criminal Procedure, ed. Roberto E. Kostoris, Cham: Springer, 2018: 345. See also FRA, supra footnote 7:66.

18 FRA, supra footnote 7: 66.

19 Bachmaier Winter, supra footnote 11: 123; FRA, supra footnote 7: 66. 
11), which is governed by Directive 2016/1919/EU ${ }^{20}$. A requested person who exercises his right to appoint a lawyer in the issuing MS and who is the subject of a prosecution-EAW has the right to legal aid in the issuing MS for the purpose of EAW proceedings in the executing MS, but only insofar as legal aid is necessary to ensure effective access to justice (Art. 5(2) of Directive 2016/1919/EU) ${ }^{21}$. The rationale of the limitation to prosecution-cases is that in execution-cases the requested person already had the benefit of access to a lawyer - and possibly to legal aid - in the trial which resulted in the conviction ${ }^{22}$.

\section{THE ROLE OF THE LAWYER IN THE ISSUING MS}

The role of the lawyer in the issuing MS, as envisaged by Art. 10(4), is limited and oriented towards the EAW proceedings in the executing MS. He assists the lawyer in the executing MS by providing information and advice to the lawyer in the executing MS with a view to the effective exercise of the requested person's rights under FD 2002/584/JHA. The wording of the directive is more focused than the indeterminate terminology of the Commission proposal ("to carry out activities limited to what is needed to assist"). Although the Commission proposal explicitly referred to the exercise of rights in the executing $M S$ and the directive does not, the same result is achieved by the reference to providing information to the lawyer in that $M S$, which is lacking in the proposal.

Given the scope of the lawyer's role, "dual representation" is not intended to enable the requested person to resist surrender at both ends. Clearly, assisting the lawyer in the executing MS by providing him with information and advice does not include challenging the EAW or the national judicial decision on which the EAW is based in the issuing MS.

20 Directive 2016/1919/EU of the European Parliament and of the Council of 26 October 2016 on legal aid for suspects and accused persons in criminal proceedings and for requested persons in European arrest warrant proceedings, OJ L 297/1.

21 See for criticisms about this provision Bargis, supra footnote 17: 346.

22 Steven Cras, "The Directive on the Right to Legal Aid in Criminal and EAW Proceedings. Genesis and Description of the Sixth Instrument of the 2009 Roadmap", eucrim 1(2017): 41-42. 
A fortiori, the same holds true for informal ways to "resolve" the EAW in the issuing MS, e.g., by negotiating a voluntary return of the requested person to that MS. Besides, there is no right under FD 2002/584/JHA to challenge the national judicial decision or to "resolve" the EAW. The criminal proceedings or the enforcement proceedings in the issuing MS are not governed by EU law but by national fundamental rights and the $\mathrm{ECHR}^{23}$.

However, when the EAW is issued by a public prosecutor who takes part in the administration of justice the decision to issue the EAW and the proportionality thereof "must be capable of being the subject, in the [issuing MS], of court proceedings which meet in full the requirements inherent in effective judicial protection" ${ }^{24}$. Providing for a separate appeal against the decision to issue the EAW is one of the ways in which a MS can discharge itself of the obligation to guarantee the required level of judicial protection $^{25}$.

Against this background, according to Advocate General Campos Sánchez-Bordona, Art. 10(5) obliges the issuing MS to facilitate the appointment of a lawyer in that MS "with a view, obviously, to making it easier for [the requested person] to exercise his right to effective judicial protection before the courts of the issuing [MS] without having to wait for his surrender" ${ }^{26}$. Clearly, this assertion flies in the face of the wording of Art. 10(4), which limits the assistance of the lawyer in the issuing MS to providing information and advice. Unlike the Advocate General, the Court of Justice did not link the right to appoint a lawyer in the issuing MS directly to the right to effective judicial protection in that MS under FD 2002/584/JHA. Instead, it remarked that FD 2002/584/JHA accords well with the general system of guarantees concerning effective judicial

23 See, e.g., ECJ, judgment of 25 May 2018, Minister for Justice and Equality (Deficiencies in the system of justice), C-216/18 PPU, ECLI:EU:C:2018:586, \$57.

24 ECJ, judgment of 27 May 2019, Minister for Justice and Equality v. OG and PI, C-508/18 and C-82/19 PPU, ECLI:EU:C:2019:456, \$75.

25 ECJ, judgment of 12 December 2019, Parquet général du Grand-Duché de Luxembourg and Openbaar Ministerie v. JR and YC, C-566/19 PPU and C-626/19 PPU, ECLI:EU:C:2019:1077, \$64-65.

26 Opinion of 26 November 2019, Parquet général du Grand-Duché de Luxembourg and Openbaar Ministerie v. JR and YC, C-566/19 PPU and C-626/19 PPU, ECLI:EU:C:2019:1012, \$89 (emphasis added). 
protection provided for by other EU instruments on judicial cooperation in criminal matters - such as provided for by Art. 10(4) - which, together, aim at facilitating the requested person in exercising his rights even before he is surrendered to the issuing $\mathrm{MS}^{27}$.

Of course, because the directive sets minimum rules (Art. 1), it does not preclude the national law of the issuing MS from assigning the lawyer in the issuing MS rights in the criminal proceedings against the requested person pending the EAW proceedings. Thus, although not envisaged by Art. 10(4), once the lawyer in the issuing MS is appointed he could also be employed to exercise the right to effective judicial protection in the issuing MS. Precisely for this reason, defence lawyers seem to consider the right to appoint a lawyer in the issuing MS as an important and beneficial tool for the requested person ${ }^{28}$.

"Dual representation" is also not intended to enable the lawyer in the issuing MS to prepare a defence in the criminal proceedings even before the requested person is surrendered, e.g., by obtaining a copy of the case-file in advance. Again, the limited "job description" does not include such activities.

Furthermore, Directive 2013/48/EU does not accord the lawyer in the issuing MS a right of access to the case-file. That right is the province of Directive 2012/13/EU on the right of information ${ }^{29}$. This directive applies from the time that persons "are made aware by the competent authorities of a Member State that they are suspected or accused of having committed a criminal offence (...)" (Art. 2(1)). If the requested person was not yet made aware of this prior to his arrest pursuant to a prosecution-EAW, one could argue that he is notified of the suspicion or accusation when the executing judicial authority (JA) informs him of the EAW and its content (Art. 11(1) of FD 2002/584/JHA). After all, the EAW must contain a reference to a national judicial decision, such as an arrest warrant, and information about the offence (Art. 8(1)(c)-(d) of FD 2002/584/JHA).

27 ECJ, supra footnote 25: \$72-73.

28 FRA, supra footnote 7: 64-65.

29 Directive 2012/13/EU of the European Parliament and of the Council of 22 May 2012 on the right to information in criminal proceedings, OJ L 142/1. Denmark is not bound by this directive. 
Consequently, Directive 2012/13/EU would apply from then on ${ }^{30}$. But Art. 7(3) of Directive 2012/13/EU does not give the lawyer an automatic right to access to the case-file: depending on the particular circumstances and the type of proceedings, disclosure can be given prior to, contemporaneous with or after the court is seized ${ }^{31}$. If, on the other hand, the expression "competent authorities of a [MS]" exclusively refers to the authorities of the MS in which the criminal proceedings are pending, then, practically speaking, the directive will only apply after surrender to that MS. In execution-cases, access to the case-file is even more problematic: Directive 2012/13/EU ceases to apply once the charge and the sentence are finally determined (Art. 2(1)). The issue of the applicability of Directive 2012/13/ EU to an accused person against whom a prosecution-EAW was issued is currently before the Court of Justice ${ }^{32}$.

To sum up: "dual representation" is not intended to facilitate challenging the EAW or the national judicial decision in the issuing MS, neither is it intended to facilitate preparing the defence in the criminal proceedings in that MS. Additionally, "dual representation" does not confer an automatic right of access to the case-file.

\section{THE REQUESTED PERSON'S RIGHTS UNDER FD 2002/584/JHA}

Now that it is clear what "dual representation" is not intended to do, it remains to be seen what is its objective. The answer depends on the meaning of the expression "the rights of requested persons under [FD] 2002/584/JHA". After all, the assistance provided by the lawyer in the issuing MS is "with a view to" the effective exercise of those rights (Art. 10(4) of Directive 2013/48/EU).

30 Compare ECJ, judgment of 12 March 2020, VW (Droit d'accès à un avocat en cas de non-comparution), C-659/18, ECLI:EU:C:2020:201, \$26, with regard to Art. 2 of Directive 2013/48/EU which to a large extent is identical with Art. 2(1) of Directive 2012/13/EU (but which also contains the words "by official notification or otherwise"): "(...) the means by which such information [i.e., information that the person concerned is to be treated as a suspect or an accused person] reaches that person is irrelevant".

31 ECJ, judgment of 5 June 2018, Kolev and Others, C-612/15, ECLI:EU:C:2018:392, \$91.

32 C-649/19 (Spetsializirana prokuratura (Déclaration des droits)). 
As we have seen (para. 1), the Commission's Explanatory Memorandum refers to the right of requested persons to consent to surrender. In this respect, assistance by a lawyer in the issuing MS can have added value: information about pending criminal proceedings against the requested person in the issuing MS for other offences than those mentioned in the EAW is relevant for the decision whether or not to consent to surrender and, at the same time, to renounce entitlement to the "speciality rule" (Art. 13(1) of FD 2002/584/JHA) 33 . Presumably, that information could be found in the case-file, but, as we have seen (see para. 3), the lawyer in the issuing MS does not have access to the case-file automatically.

In addition, the Explanatory Memorandum mentions the possibility of invoking grounds for non-execution, in particular under Art. 3 and 4 of FD 2002/584/JHA (see para. 1).

The Court of Justice has repeatedly held that the grounds for non-execution and the conditions upon which the execution of an EAW may be made dependent, are exhaustively listed in Art. 3-5 of FD 2002/584/JHA. Can these mandatory and optional grounds and these conditions be considered as "rights of requested persons under [FD] 200/584/JHA", as the Commission apparently thinks? None of these grounds or conditions is explicitly designated as a right of the requested person. As regards the mandatory grounds (Art. 3), which impose a duty on the executing JA to refuse the execution of the EAW, one can argue that the other side of the coin of a duty of the executing JA is a corresponding right of the requested person. However, the Court of Justice seems to regard Art. 3 of FD 2002/584/ JHA as a provision which leaves the MSs the possibility to implement the mandatory grounds for refusa ${ }^{34}$. In other words, the MSs seem to have the freedom to choose whether or not to implement these grounds for refusal. As regards the optional grounds (Art. 4-4a) and the conditions (Art. 5), it cannot be maintained that they are rights of requested persons under FD 2002/584/JHA. In the Wolzenburg case, it was argued by Advocate General Y. Bot that the MSs, when implementing FD 2002/584/JHA, must

33 According to this rule, a person who has been surrendered may not be prosecuted, sentenced or otherwise deprived of his liberty for an offence committed prior to his surrender other than that for which he was surrendered (Art. 27(2) of FD 2002/584/JHA).

34 ECJ, judgment of 28 June 2012, West, C-192/12 PPU, ECLI:EU:C:2012:404, \$64. 
implement the optional grounds, but the Court of Justice did not follow him $^{35}$. Accordingly, the MSs are free whether to implement the optional grounds ${ }^{36}$ and the conditions or not ${ }^{37}$. Consequently, it depends on the national law of the executing MS whether or not the requested person can invoke those grounds or conditions. Moreover, if a MS chooses to implement an optional ground, it must leave a margin of discretion to the executing JA as to whether or not it is appropriate to refuse to execute the $\mathrm{EAW}^{38}$. Such a margin of discretion is difficult to reconcile with the concept of "rights of requested persons under [FD] 2002/584/JHA"39.

In conclusion, and contrary to Commission's opinion, the grounds for non-execution and conditions enumerated in Art. 3-5 of FD 2002/584/ JHA, strictly speaking, cannot be considered as "rights of requested persons under [FD] 2002/584/JHA". In the context of grounds for non-execution and conditions, the expression "rights of requested persons under [FD] 2002/584/JHA" can refer to, at most, the grounds and conditions which the executing MS has chosen to implement and only then to those grounds and conditions which do not leave a margin of discretion to the executing JA as to their application. However, in the final analysis it does not really matter whether the grounds for non-execution and the conditions can be considered as "rights of requested persons under [FD] 2002/584/

35 ECJ, judgment of 6 October 2008, Dominic Wolzenburg, C-123/08, ECLI:EU:C:2009:616, \$58; see also ECJ, judgment of 29 June 2017, Poptawski, C-579/15, ECLI:EU:C:2017:503, \$21.

36 Concerning Art. 4a, see recital (15) of Council Framework Decision 2009/299/ JHA of 26 February 2009 amending Framework Decisions 2002/584/JHA, 2005/214/ JHA, 2006/783/JHA, 2008/909/JHA and 2008/947/JHA, thereby enhancing the procedural rights of persons and fostering the application of the principle of mutual recognition to decisions rendered in the absence of the person concerned at the trial, OJ L 81/24.

37 ECJ, judgment of 21 October 2010, I.B., C-306/09, ECLI:EU:C:2010:626, \$51, concerning Art. 4(6) and 5(3).

38 ECJ, Poptawski, supra footnote 35: \$21, concerning Art. 4(6).

39 To be absolutely clear: at issue here is the meaning of the expression "rights of requested persons under [FD] 2002/584/JHA", not whether such rights have direct effect in the legal systems of the MSs. Unlike provisions of directives, provisions of FDs cannot have direct effect, regardless of whether a FD provision is sufficiently precise and unconditional. See, e.g., ECJ, judgment of 8 November 2016, Ognyanov, C-554/14, ECLI:EU:C:2016:835, \$56-57. 
JHA". After all, when exercising the right to be heard by the executing JA (Art. 14 of FD 2002/584/JHA), the requested person and his lawyer in the executing MS (Art. 10(2)(c) of Directive 2013/48/EU) can point to the grounds for non-execution and conditions as implemented by the executing MS. Therefore, we have to examine whether and to what extent the assistance of a lawyer in the issuing MS can have added value for invoking them.

The overwhelming majority of the grounds for non-execution and conditions mentioned in Art. 3-5 of FD 2002/584/JHA cover factual and legal situations which are particular to the executing MS or to a third State. It is difficult to see what added value, if any, information and advice provided by the lawyer in the issuing MS could have for invoking these grounds or conditions. Besides, if the executing JA applies a ground for non-execution belonging to this category, this does not mean that the EAW was wrongly issued (compare para. 1). After all, the cause of non-execution does not relate to the issuing MS.

The few remaining grounds for non-execution and conditions concern factual and legal situations which are particular to or which may occur in the issuing MS, e.g. the mandatory ground for non-execution based on the ne bis in idem-principle (Art. 3(2)), the optional ground for non-execution concerning in absentia judgments (Art. 4a) and the condition concerning the possibility to reduce a life sentence (Art. 5(2) $)^{40}$. The lawyer in the issuing MS can try to produce evidence that the EAW relates to offences for which the requested person was already finally sentenced - evidence which would probably be contained in the case-file $--^{41}$, can provide legal information showing that a certain way of serving a summons on a defendant in the issuing MS does not fulfill the requirements of Art. $4 a(1)(a)$ of FD 2002/584/JHA ${ }^{42}$ or can refer to judgments of the ECtHR showing that a life sentence imposed in the issuing MS is not de jure or de facto reduci-

40 See also Art. 4(3): a final judgment in a MS with regard to the same act which prevents further proceedings.

41 For a - somewhat atypical - case see: ECJ, judgment of 16 November 2010, Mantello, C-261/09, ECLI:EU:C:2010:683.

42 See ECJ, judgment of 24 May 2016, Dworzecki, C-108/16 PPU, ECLI:EU:C:2016:346. 
ble $^{43}$. In these situations, information provided by the lawyer in the issuing MS can have added value, although the possibility to provide information from the case-file may be limited (see para. 3).

Assistance by a lawyer in the issuing MS also is relevant for invoking the fundamental rights-based grounds for non-execution developed in the Court of Justice's case-law. Because those grounds for non-execution are based on the Court of Justice's interpretation of Art. 1(3) of FD 2002/584/ JHA - which, in essence, refers to the duty to respect the Charter - in conjunction with rights which the Charter confers on anyone when MSs are implementing Union law (Art. 51(1) of the Charter), e.g. when their judicial authorities apply the national provisions adopted to transpose FD $2002 / 584 / \mathrm{JHA}^{44}$, there is no difficulty in recognizing those grounds as "rights of requested persons under [FD] 2002/584/JHA". If, on the basis of a two prong test, the executing JA concludes that executing the EAW would expose the requested person to a real risk of a violation of Art. 4 of the Charter on account of deficiencies with regard to detention conditions in the issuing $\mathrm{MS}^{45}$ or to a real risk of a violation of the right to an independent court and therefore of the right to a fair trial as guaranteed by Art. 47(2) of the Charter on account of deficiencies with regard to the independence of the judiciary in the issuing MS, it must not execute the $\mathrm{EAW}^{46}$. The lawyer in the issuing MS is probably better placed than the lawyer in the executing MS to adduce evidence based on "judgments of international courts, such as judgments of the ECtHR, judgments of courts of the issuing [MS], and also decisions, reports and other documents produced by bodies of the Council of Europe or under the aegis of the UN"47 that there is a general real risk of a violation in the issuing MS (first prong of the test). In the same vein, the lawyer in the issuing MS may have easier access to information showing that the requested person runs an individual real risk of a violation (second prong of the test).

43 See, e.g., ECtHR, judgment of 23 May 2017, Matiošaitis e.a. v. Lithuania, ECLI:CE:ECHR:2017:0523JUD002266213.

44 ECJ, judgment of 5 April 2016, Aranyosi and Căldăraru, C-404/15 and C-659/15 PPU, ECLI:EU:C:2016:198, \$84.

45 ECJ, supra footnote 44: $\$ 104$.

46 ECJ, supra footnote 23: \$79.

47 ECJ, supra footnote 44: $\$ 89$. 
If the EAW is not executed because of a ground for non-execution belonging to one of the previous two categories, it could be said that the EAW was issued wrongly. Therefore, information and advice regarding these grounds for non-execution could contribute to the prevention of incorrectly issued EAWs and, thereby, could facilitate judicial cooperation (see para. 1).

At this junction, we should touch upon a relevant side-issue. Given the limitation of legal aid to prosecution-cases (see para. 2), it should be stressed that both categories contain grounds for non-execution which relate or can relate to execution-cases. The rationale for that limitation in execution-cases, the requested person already had the benefit of access to a lawyer in the criminal proceedings resulting in the final conviction (see para. 2) - does not take into account that even in execution-cases, some grounds for non-execution relate to possible events in the future. In an execution-case, the requested person could argue, e.g., that in case of surrender he would be subjected to inhuman or degrading conditions of detention in the issuing MS. In this respect, the fact that the requested person had the benefit of access to a lawyer in the criminal proceedings leading to his conviction is completely irrelevant, whereas assistance by a lawyer in the issuing MS could be very pertinent to this defence against surrender (see above). Therefore, the rationale does not support a blanket exclusion of execution-cases.

Turning once again to the meaning of the expression "rights of requested persons under [FD] 2002/584/JHA", it remains to be determined whether that expression can have any relation to the substance of the criminal case in the issuing MS. In accordance with the principle of mutual recognition none of the grounds for non-execution or the conditions explicitly provided for in FD 2002/584/JHA, as well as none of the obstacles to execution of the EAW developed in the Court of Justice's case-law allow for a review of the merits of the case by the executing $\mathrm{JA}^{48}$. EAW proceedings do not involve the determination of a criminal

48 Recital (22) of the Commission proposal for Directive 2013/48/EU stated - quite redundantly - that, because of the principle of mutual recognition, assisting the lawyer in the issuing MS should not entail a right to question the merits of the case. One could also point to the principle of mutual trust as a foundation of the prohibition to review the merits of the case: ECJ, judgment of 9 September 2015, Bohez, C-4/14, ECLI:EU:C:2015:563, \$43-44. 
charge ${ }^{49}$. That determination will take place or has already taken place in the issuing MS. Accordingly, the EAW form, which is intended to provide "the minimum official information required to enable [the executing JAs] to give effect to the [EAW] swiftly by adopting their decision on the surrender as a matter of urgency" ${ }^{50}$, does not refer to evidence that the requested person committed the offence nor to facts or information which would support a reasonable suspicion of his having committed the offence. Under Art. 6 of the Charter, which in the context of EAW proceedings corresponds to Art. 5(1)(f) of the ECHR (see Art. 52(3) of the Charter $)^{51}$, a reasonable suspicion is not necessary for arrest and detention on the basis of an EAW. ${ }^{52}$ It follows that the merits of the case should not be the subject of information and advice provided by the lawyer in the issuing MS.

To recapitulate: the assistance of a lawyer in the issuing MS can have added value for the effective exercise of the right to consent to surrender and to renounce entitlement to the speciality rule, for invoking a small number of grounds for non-execution and conditions explicitly mentioned in FD 2002/584/JHA and for invoking the fundamental rightsbased grounds for non-execution developed by the Court of Justice. For those three - limited - categories, information and advice provided by a lawyer in the issuing MS can facilitate judicial cooperation by promoting "informed" consent to surrender, by improving the quality of the decision on the execution of the EAW and by reducing the incidence of EAWs which were issued wrongly.

49 ECtHR, supra footnote 5.

50 ECJ, judgment of 6 December 2018, IK, C-551/18 PPU, ECLI:EU:C:2018:991, \$50.

51 ECJ, judgment of 16 July 2015, Lanigan, C-237/15 PPU, ECLI:EU:C:2015:474, $\$ 56-58$.

52 It is settled case-law that Art. 5(1)(c) of the ECHR - referring to a reasonable suspicion of having committed an offence - does not apply to detention with a view to extradition: see, e.g., ECtHR, decision of 26 May 2005, Parlanti v. Germany, ECLI:CE:ECHR:2005:0526DEC004509704 and ECtHR, judgment of 24 July 2014, Ćalovskis v. Latvia, ECLI:CE:ECHR:2014:0724JUD002220513, \$180. Art. 5(1)(f) does not require a prima facie case before a requested person can be detained with a view to extradition: ECtHR, decision of 6 July 2010, Babar Ahmad and Others v. the United Kingdom, ECLI:CE:ECHR:2010:0706DEC002402707, \$180. 


\section{THE DUTY TO OBSERVE THE TIME-LIMITS}

Art. 10(6) of Directive 2013/48/EU takes great pains to stress the importance of the time-limits set out in FD 2002/584/JHA, by referring to the duty to observe these time-limits twice (the right to appoint a lawyer in the issuing MS "is without prejudice to the time-limits set out in [FD] 2002/584/JHA or the obligation on the executing [JA] to decide, within those time-limits and the conditions defined under that [FD] (...)").

Art. 17 of FD 2002/584/JHA sets out the time-limits for the decision to execute the EAW. They express the object of FD 2002/584/JHA of accelerating judicial cooperation in criminal matters ${ }^{53}$. If the requested person does not consent to his surrender, the final decision on the execution of the EAW must be taken within 60 days from the time of his arrest (Art. 17(3)). In "specific cases" where the EAW cannot be executed within that time-limit, it may be extended with a further 30 days (Art. $17(4))$. Only in "exceptional circumstances" is it allowed to exceed those 90 days (Art. 17(7)). To date, the Court of Justice has only recognized that such exceptional circumstances are present when the executing JA must assess whether the requested person, if surrendered, will suffer inhuman or degrading treatment (Art. 4 of the Charter) or a breach of his right to an independent tribunal (Art. 47(2) of the Charter) in the issuing MS, or when the executing JA decides to make a reference to the Court of Justice for a preliminary ruling ${ }^{54}$.

The references to the time-limits convey a double message. Exercising the right to appoint a lawyer in the issuing MS must not prolong the EAW proceedings ${ }^{55}$. In other words, exercising that right does not justify exceeding either the limit of 60 days or that of 90 days. Furthermore, exercising that right, in itself, cannot be a reason not to execute the EAW, because the grounds for non-execution are exhaustive and, beyond these, limitations on the principles of mutual trust and mutual recognition may be only be

53 ECJ, judgment of 30 May 2013, Jeremy F, C-168/13 PPU, ECLI:EU:C:2013:358, \$58.

54 ECJ, judgment of 12 February 2019, TC, C-492/18 PPU, ECLI:EU:C:2019:108, \$43.

55 That, at least, is the opinion of four MSs: Austria: $1300 \operatorname{der}$ Beilagen XXV. GP Regierungsvorlage - Erläuterungen, 17; Belgium: 54 2030/001, 26; Germany: Bundestag Drucksache 18/9534, 19; the Netherlands: Kamerstukken II 2014/15, 34157, 3, 57. 
made in "exceptional circumstances" 56 . The obligation of the competent authorities to inform and to provide information without undue delayl promptly, together with the limited scope of review by the executing JA and the limited role of the lawyer in the issuing MS (see paras. 3 and 4), should ensure that the right to appoint a lawyer in the issuing MS can be exercised without exceeding the time-limits.

In this respect it is worrying that five MSs do not clearly provide for the obligation to provide information about that right without undue delay, that the legislation of seven MSs fails to reflect the requirement that the competent authority in the executing MS promptly informs the competent authority in the issuing MS of the requested person's wish to appoint a lawyer and that ten MSs did not transpose the latter authority's obligation to provide without undue delay the requested person with information to facilitate the appointment of a lawyer ${ }^{57}$.

Moreover, in some MSs the competent authorities do not seem to provide information about the right to appoint a lawyer in the issuing MS at all ${ }^{5}$. This brings us to the issue of remedies in the event of a breach of the right to appoint a lawyer in the issuing MS.

\section{THE RIGHT TO AN EFFECTIVE REMEDY}

A breach of the right to appoint a lawyer in the issuing MS occurs when the competent authorities of either MS fail to live up to their obligations. According to Art. 12(1) of Directive 2013/48/EU, MSs must ensure that not only "suspects or accused persons in criminal proceedings" but also "requested persons in [EAW] proceedings" have an effective remedy

56 ECJ, supra footnote 23: $\$ 41-43$.

57 Report from the Commission to the European Parliament and the Council on the implementation of Directive 2013/48/EU of the European Parliament and of the Council of 22 October 2013 on the right of access to a lawyer in criminal proceedings and in European arrest warrant proceedings, and on the right to have a third person informed upon deprivation of liberty and to communicate with third persons and with consular authorities while deprived of liberty, $\operatorname{COM}(2019) 560$ final, 18.

58 FRA, supra footnote 7:65 (three out of the eight MSs involved in the research). However, one of those three MSs is Denmark, which is not bound by the directive. 
under national law in the event of a breach of the rights under the directive. The interpretation of this provision presents quite a challenge as to the where and when of that remedy and as to its scope.

The most obvious and effective remedy would be to enable the competent authorities to live up to their obligations in order that the requested person can still exercise his right. In other words, to restore the requested person to the situation existing before his right was breached ${ }^{59}$. This would require a remedy in the executing MS before he is surrendered.

The wording of Art. 12(1) seems to indicate that the effective remedy for a breach of the right to appoint a lawyer in the issuing MS must indeed be available in the executing MS during the EAW proceedings. After all, once the requested person is surrendered to the issuing MS, he no longer is a requested person in EAW proceedings. One could also cite Art. 2(2) in support of this reading: according to this provision, the directive applies to "persons subject to [EAW] proceedings (requested persons) from the time of their arrest in the executing [MS] in accordance with Article 10"60.

If this interpretation is correct, does it follow that the remedy must respect the time-limits? That is the opinion of both legislator and executing JA in at least one MS, the Netherlands: because of the duty to observe the time-limits, the directive does not attach any consequence to a failure to act by the competent authority in the issuing MS and such a failure does not justify exceeding the time-limits ${ }^{61}$. However, in itself the wording of Art. 12(1) is unconditional (in that it does not refer to the time-limits), clear and precise. Consequently, it seems that the provision should be interpreted as precluding any national measure which impedes the exercise of the effective remedy ${ }^{62}$. This interpretation would not leave any room for the time-limits as obstacles to a remedy.

59 Compare Anneli Soo (2017), supra footnote 11:31-51, with respect to suspects or accused persons.

60 Compare Anneli Soo (2016), supra footnote 11: 297, concerning suspects or accused persons.

${ }^{61}$ Kamerstukken II 2015/16, 34157, 6, 37; (e.g.) District Court of Amsterdam, judgment of 8 August 2017, ECLI:NL:RBAMS:2017:5781.

62 ECJ, judgment of 19 September 2019, Rayonna Prokuratura Lom, C-467/18, ECLI:EU:C:2019:765, \$57-58, with regard to suspects and accused persons. 
On the other hand, one could argue that when it comes to requested persons, Art. 12(1) should not be interpreted in isolation from the EAW regime established by FD 2002/584/JHA. Because the "entire surrender procedure between [MSs] provided for by [FD] 2002/584/JHA is (...), in accordance with that decision, carried out under judicial supervision", the provisions of FD 2002/584/JHA already provide for an effective remedy as required by Art. 47(1) of the Charter ${ }^{63}$. It would follow that the requested person can complain to the executing JA about a breach of his rights ${ }^{64}$. As we have seen, the proceedings before that authority must comply with the time-limits. If the executing MS provides for a separate effective remedy with suspensive effect against the decision to execute the EAW, then that remedy must equally respect those time-limits ${ }^{65}$. It would seem inconsistent if an effective remedy for a breach of the right to appoint a lawyer in the issuing MS would not have to respect them.

If we accept that interpretation of Art. 12(1), we still have to square the impediment to providing appropriate redress where this would entail non-observance of the time-limits with the right to an effective remedy as guaranteed by Art. 47(1) of the Charter. This impediment is a limitation on that right. Arguably, this limitation is justified because it fulfills the requirements of Art. 52(1) of the Charter. Concerning, in particular, the proportionality of the limitation, in general the disadvantages for the requested person do not seem disproportionate to the objective pursued, given the limited role of the lawyer in the issuing MS, the limited scope of review by the executing JA which does not extend to the merits of the case and the fact that the requested person has the right of access to a lawyer executing MS anyway. Moreover, because of the limited scope of review by the executing JA, its decision on the execution of the EAW can have no influence on the fairness of the criminal proceedings in the issuing $\mathrm{MS}^{66}$.

63 ECJ, supra footnote 53: $\$ 46-47$.

64 For this reason, the Dutch legislator and the German legislator were of the opinion that Art. 12(1) did not need transposition into national law: Kamerstukken II 2014/15, 3, 57; Bundestag Drucksache 18/9534, 19.

65 ECJ, supra footnote 53: $\$ 65$.

66 To the contrary: Anagnostopoulos, supra footnote 11: 17-18, who refers to ECtHR, judgment of 27 October 2011, Stojkovic v. France and Belgium, ECLI:CE:ECHR:2011:1027JUD002530308. In the context of EAW proceedings, the reference to that judgment 
But a ban on affording redress even in cases where this would be possible without exceeding the maximum limit of 90 days or in cases where there are "exceptional circumstances" justifying non-observance of the time-limits anyway, would seem to be disproportionate.

These somewhat tentative conclusions on the meaning of Art. 12(1) are prompted by the fact that the Court of Justice emphasizes the primary responsibility of the issuing MS for observing the rights of the requested person and the opportunity to challenge the validity of his detention within the legal system of that MS after surrender ${ }^{67}$. Furthermore, the Court of Justice accepts that effective judicial protection against the decision to issue an EAW may also be given after surrender ${ }^{68}$. Therefore, notwithstanding the wording of Art. 12(1), another possible reading of Art. 12(1) is that it allows for a remedy for a breach of the right to appoint a lawyer in the issuing MS - or, at least, for a breach originating in a failure on the issuing MS's part - to be given in the issuing MS after surrender.

\section{CONCLUSIONS AND FINAL CONSIDERATIONS}

According to the Commission, overall the directive has provided the EU added value ${ }^{69}$. With respect to the right to appoint a lawyer in the issuing MS, this statement should be qualified. Although the literature has hailed the introduction of that right as a major development ${ }^{70}$, it can only contribute to its objective of facilitating judicial cooperation to a rather limited extent, because of the limited role of the lawyer, the limited scope of review in the executing MS and the duty to observe the time-limits (see paras. 3-5). This potential added value, such as it is, partly depends on

is somewhat puzzling, because, unlike in mutual assistance proceedings such as those at issue in the Stojkovic judgment, in EAW proceedings the requested person is not questioned by the executing JA as to the merits of the case.

${ }_{67}$ ECJ, supra footnote 50: $\$ 66-67$.

68 ECJ, order of 21 January 2020, MN, C-813/19 PPU, ECLI:EU:C:2020:31, \$52.

69 Commission, supra footnote 57: 20.

70 Bachmaier Winter, supra footnote 11: 123 ("an important progress"); Bargis, supra footnote 17: 345 ("innovating”); Jimeno-Bulnes, supra footnote 11: 66 ("an important novelty"). 
having access to the case-file in the issuing MS which in prosecution-cases, at best, is not automatic and, at worst, is only possible after surrender (see para. 3). Moreover, the competent authorities of both MSs are only required to do the bare minimum to help the requested person to exercise his right (see para. 2). A major practical impediment is the limited right to legal aid. Although the rationale for not providing legal aid in execution-cases (see para. 2) certainly fits in with the Court of Justice's case-law that the executing JA may assume that a convicted requested person already benefitted from all the guarantees appropriate for a trial, in particular fundamental rights ${ }^{71}$, it does not apply when the requested person wants to argue a future violation of a fundamental right. In such cases, at least, the distinction between prosecution and execution-EAWs does not seem justified (see para. 4).

To be sure, as recital (12) of the preamble to Directive 2013/48/EU reminds us, conferring the right to appoint a lawyer in the issuing MS on the requested person promotes the application of his fundamental right to fair EAW proceedings under Art. 47(2) of the Charter (see para. 1). No one would deny that promoting the fairness of EAW proceedings is an important goal in itself. However, the relevant provisions of Directive 2013/48/ EU have a strong utilitarian approach: their aim is to facilitate judicial cooperation. By linking the right to appoint a lawyer in the issuing MS exclusively to the effective exercise of the "rights of requested persons under [FD] 2002/584/JHA", Directive 2013/48/EU rather overestimates the relevance of assistance by a lawyer in the issuing MS for reaching that aim.

Of course, as limited as it may be, the effectiveness of the right to appoint a lawyer in the issuing MS in facilitating judicial cooperation should not be compounded even further - as it is now - by non-implementation of the relevant provisions and non-application of the national implementing legislating (see para. 5). Uncertainty concerning the scope of the right to an effective remedy can have an additional negative effect (see para. 6).

In practice, the right to appoint a lawyer in the issuing MS seems more relevant because of its unintended corollary: through the lawyer in the issuing MS the requested person can challenge the EAW and the national

71 ECJ, judgment of 12 December 2019, Openbaar Ministerie (Procureur du Roi de Bruxelles), C-627/19 PPU, ECLI:EU:C:2019:1079, \$36. 
judicial decision before the courts of that MS or try to resolve the EAW in a more informal way, while he is still in the executing MS (see para. 3).

This important conclusion leads us to some final considerations. A decision not to execute the EAW does not invalidate the national judicial decision on which the EAW is based, does not bar further proceedings in the issuing MS and, in principle, does not preclude maintaining the $\mathrm{EAW}^{72}$ or issuing a new EAW for the same acts against the same requested person $^{73}$. From his perspective, it makes perfect sense to invest equal, if not more energy in challenging the EAW and the national judicial decision in the issuing MS before the decision on the execution of the EAW is taken.

Should Directive 2013/48/EU be brought into line with practice by extending the role of the lawyer in the issuing MS to exercising legal avenues in the issuing MS before the requested person is surrendered? Arguably, this could have a positive effect on mutual trust and thus facilitate judicial cooperation. An unsuccessful challenge would all the more assure the executing JA of the soundness of the EAW, a successful challenge would accentuate the effectiveness of judicial protection in the issuing MS and would obviate the need to decide on the execution of an EAW which should not have been issued. This would also be in keeping with the Court of Justice's case-law which stresses the requested person's entitlement to effective judicial protection in the issuing MS. The problem, however, would be squaring an extension of the role with the duty to observe the time-limits.

In the end, the best way to avoid the execution of EAWs which should not have been issued is to see that such EAWs are not issued at all, but that would require legal and practical measures which lay outside the scope of this article.

72 Commission, Handbook on how to issue and execute a European arrest warrant, OJ 2017 C 335/41.

73 ECJ, judgment of 25 July 2018, AY (Arrest warrant - witness), C-268/17, ECLI:EU:C:2018:602, $\$ 36$. But it cannot be excluded that the duty to respect fundamental rights requires the issuing JA to withdraw an EAW: $\$ 28-29$. 


\section{REFERENCES}

Anagnostopoulos, Ilias, 2014, "The Right of Access to a Lawyer in Europe: A Long Road Ahead?", European Criminal Law Review, 1: 3-18.

Armenta Deu, Teresa, Urban, Lisa, 2018, "The Right of Access to a Lawyer under Directive 2013/48/EU”, In: Effective Defence Rights in Criminal Proceedings. A European and Comparative Study on Judicial Remedies, ed. Silvia Allegrezza, Valentina Covolo, 65-79, Milano: Wolters Kluwer.

Bachmaier Winter, Lorena, 2015, "The EU Directive on the Right to Access to a Lawyer: A Critical Assessment", In: Human Rights in European Criminal Law. New Developments in European Legislation and Case Law after the Lisbon Treaty, ed. Stefano Ruggeri, 111-131, Cham: Springer.

Bargis, Martha, 2018, "Personal Freedom and Surrender", In: Handbook of European Criminal Procedure, ed. Roberto E. Kostoris, 297-352, Cham: Springer. Commission, 2017, Handbook on how to issue and execute a European arrest warrant, OJ 2017 C 335/1.

Commission, 2019, Report from the Commission to the European Parliament and the Council on the implementation of Directive 2013/48/EU of the European Parliament and of the Council of 22 October 2013 on the right of access to a lawyer in criminal proceedings and in European arrest warrant proceedings, and on the right to have a third person informed upon deprivation of liberty and to communicate with third persons and with consular authorities while deprived of liberty, $\operatorname{COM}(2019) 560$ final.

Cras, Steven, 2014, "The Directive on the Right of Access to a Lawyer in Criminal Proceedings and in European Arrest Warrant Proceedings", eucrim 1: 32-44.

Cras, Steven, 2017, "The Directive on the Right to Legal Aid in Criminal and EAW Proceedings. Genesis and Description of the Sixth Instrument of the 2009 Roadmap", eucrim 1: 34-45.

Đurđević, Zlata, 2016, "The Directive on the Right of Access to a Lawyer in Criminal Proceedings: Filling a Human Rights Gap in the European Union Legal Order”, In: ed. Zlata Đurđević, Elizabeta Ivičević Karas, European Criminal Procedure Law in Service of the Protection of European Union Financial Interests: State of Play and Challenges, 9-23, Zagreb: Croatian Association of European Criminal Law.

EU Fundamental Rights Agency, 2019, Rights in practice: access to a lawyer and procedural rights in criminal and European arrest warrant proceedings, Luxembourg: Publications Office of the European Union. 
Fair Trials, 2018, Beyond Surrender. Putting human rights at the heart of the European Arrest Warrant. $2^{\text {nd }}$ May, 2020, https://www.fairtrials.org/publication/beyond-surrender.

Jimeno-Bulnes, Mar, 2019, "The Right of Access to a Lawyer in the European Union: Directive 2013/48/EU and Its Implementation in Spain”, In: EU Criminal Justice. Fundamental Rights, Transnational Proceedings and the European Public Prosecutor's Office, ed. Tommasso Rafaraci, Rosanna Belfiore, 57-70, Cham: Springer.

Soo, Anneli, 2016, "Potential Remedies for Violation of the Right to Counsel in Criminal Proceedings: Article 12 of the Directive 2013/48/EU (22 October2013) and its Output in National Legislation”, European Criminal Law Review, 3: 284-307.

Soo, Anneli, 2017, "Article 12 of the Directive 2013/48/EU: A Starting Point for Discussion on a Common Understanding of the Criteria for Effective Remedies of Violation of the Right to Counsel", European Journal of Crime, Criminal Law and Criminal Justice, 1: 31-51.

Symeonidou-Kastanidou, Elisavet, 2015, "The Right of Access to a Lawyer in Criminal Proceedings: The transposition of Directive 2013/48/EU of 22 October 2013 on national legislation", European Criminal Law Review 5: 68-85. 
